\title{
DESIGN OF DENOTATIVE AND DIRECTIVE TEXT POSTER AS COGNITIVE STIMULANT IN BASIC EDUCATION INSTITUTION
}

\author{
Fauzi Rahman, Amri Azhari \\ Faculty of Language and Arts, University of Indraprasta PGRI, Indonesia. \\ Email: fauzierachman20@yahoo.com
}

\begin{abstract}
In the directive function, the language not only keeps the listener doing something, but also performs the activities that the speaker wants. The directive function is oriented to the message recipient. Based on the directive function of this language, it is hoped that this activity can be effectively applied to students as learners in the school to get positive messages from sentences that will be visualized in the school environment in the form of educative posters. This research is conducted in thise basic education institutions have targeted the achievement of $s$ research is conducted in this basic educational institution has the target of achievement among which is giving education through poster design work which socialize code of ethics to solve common problem in school environment.. By making design work based on the need to raise the school code of ethics, it is hoped that this kind of community service activity will change the way of thinking of the school people to practice the behavior of the code of ethics both in school and community.
\end{abstract}

Keywords: Poster, Denotative Text, Cognitive Stimulant, Basic Education

\section{INTRODUCTION}

Basic education is the level of institution received by the next generation of the nation with an age range between 6-15 years. In that age, the school provides knowledge as a basic stock in continuing to the next level. These basic supplies include integrated knowledge, a humanistic ethical touch to interact with social friends, and provide choices such as the development of talent interests.

Educational institutions, especially schools, in the same regulation are required to apply the code of ethics that has been identified through the Regulation of the Minister of National Education of Indonesia Number 19 of 2007, among others, (1) to perform the worship in accordance with the religion it embraces; (2) respect for educators and education personnel; (3) follow the learning process by upholding the provisions of the lesson and complying with all applicable regulations; (4) maintaining harmony and peace to achieve social harmony among friends; (5) loving family, community, and loving others; (6) love the environment, nation and state; And (7) maintain facilities and infrastructure, hygiene, orderliness, safety, beauty, and comfort of the school.

Furthermore, it often appears in the school environment of educational issues that often appear as fights, bullying, and hostility that always happens to students. In fact, if further examined points of ethic code number four to maintain harmony and peace to realize social harmony among friends, is the value content that must be implemented by every citizen of the school.

School managers often override the display of visual information as a cognitive trigger strategy in the school environment. This reasoning is caused by several factors such as (1) unavailability of internal human resources assigned as graphic designer, (2) lack of serious 
priority scale in discussing and making educational display about code of ethics that attract attention for school citizen, (3) ) The perception of "expensive cost" that must be issued by schools to form visual information in accordance with the code of ethics that should be socialized. These three factors must be part of the task of researchers who have a background of education, especially Indonesian language with visual communication design. The integration of these two scholarship will be part of realizing informative posters capable of providing cognitive stimulation for school residents.

\section{METHOD}

The method of implementation to be determined in this research is by reviewing the activity in the school environment. This review was conducted to identify the behavioral criteria of schoolchildren who are often incompatible with the codes of conduct that should be practiced within the school setting. Furthermore, the researchers Set the choice of the language of denotative message directive, the research team began to make informative posters that can be easily seen, read, and understood by the citizens of the school. After all these standards are established then the researcher has entered into the work area design ideas in which is the creation process of the research team to achieve the expected standard objectives.

\section{FINDINGS AND DISCUSSION}

Indonesian as a scientific language becomes an integral part in the field of education, especially at the level of basic education. Language can be used for various functions. According to Mohn and Pelka (Patocka, 2011), there are some basic functions of language in relation to scientific language. (1) Descriptive function: describes the objective exposure of a thing or thing, for example the text of a physician's findings; (2) instructive functions: provide direction, instruction, suggest, eg recipe text and instructional text on how to use new goods; (3) directive functions: ordering to do something, eg legal text, test referral text, and military orders; (4) the function of the contact: social relationships, such as greeting and postcard text; (5) expressive functions: subjective submission, such as love letters, condolences, and scorns; (6) metalingual functions: statements about the language itself, such as dictionaries, lexicon, and printed text; (7) isolative functions: language functions limited only to specific users, such as thugs.

Based on the above explanation, there is a function of language as a directive function or in another sense is as a tool to govern in doing something. In the directive function, the language not only keeps the listener doing something, but also performs the activities that the speaker wants. Based on the directive function of this language, it is hoped that this activity can be effectively applied to students as learners in the school in order to get positive messages from sentences that will be visualized in the school environment in the form of educative posters.

Posters according to Anitah (2008, p.12) is an image that combines visual elements such as lines, drawings and words that intend to attract attention and communicate the message briefly. Therefore, in the poster can be written sentences that have a directive meaning even in it there is only a short article. This is certainly in line with the function of posters according to Sudjana and Rivai (2010, p.56-57): (1) motivating students, posters in learning as a driver or motivating student learning; (2) a warning, containing warnings against an implementation of the rule of law, school, or social, health and even religious; (3) creative experiences, through poster activities become more creative to create ideas, stories, essays from a poster on display. 
In day activities, everyone has done the design work, it was confirmed by V. Papanek who quotes Jhon A Walker (2010, p.33) explains that every human being is a designer. What has been done all the time, is design, because design is fundamental to all human activities. Planning and commencement of each action towards a desired and predictable goal is a design process.

furthermore, affirmed by Paulo Freire (in Sachari, 2002, p.27) explains that aesthetic art and values are often seen only as an attempt to express creativity through an art medium unattached to paint and canvas, tone, motion and even the body own. But when viewed through the framework of social theory and critical culture, then what is practiced artists can only be understood not merely as a ritual activity of a mere artist. More than that what is thought and done with the community is the field application of a concept which he calls the cultural act of liberation.

This poster serves as a medium for delivering messages. Media is able to give influence to the society as revealed by Kriyantono (2007) that media organizations distribute messages that not only influence but also reflect the culture of a society. So what happens in the media describes what happens in the community.

This study took samples in a primary school, namely is SD Negeri 1 Nagrak, Gunungputri Sub-district, Bogor Regency, Indonesia (the sample schools), with several completion targets. Among others,

1. Optimizing the role of poster design with different styles of language as well as illustrations for educational purposes in sample schools.

2. Procurement of poster design also beautify the exterior appearance in sample schools environment.

Here are the results of the planning activities that have been done in the sample schools,

\section{Location Survey at SD Negeri 1 Nagrak}

The survey was conducted on Friday, May 27, 2016 at the location of SD Negeri 1 Nagrak with address J1. KH. Rafei RT 01/03 Nagrak Village, Gunung Putri District, Bogor Regency, West Java, Indonesia.

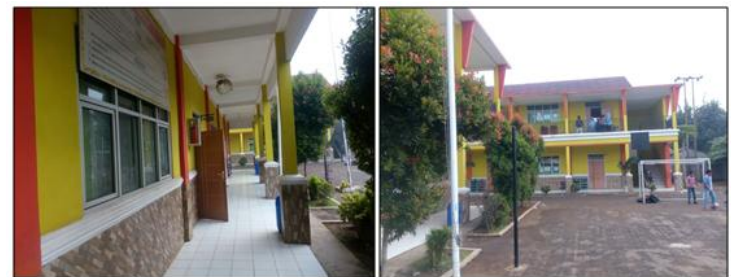

1st Figure: SD Negeri 1 Nagrak Building, Nagrak Village

The survey in this study focuses more on mapping the location of the school (sitemap), building documentation efforts, and viewing student activities as a visual reference clothing that will be used as an inspiration illustration. 


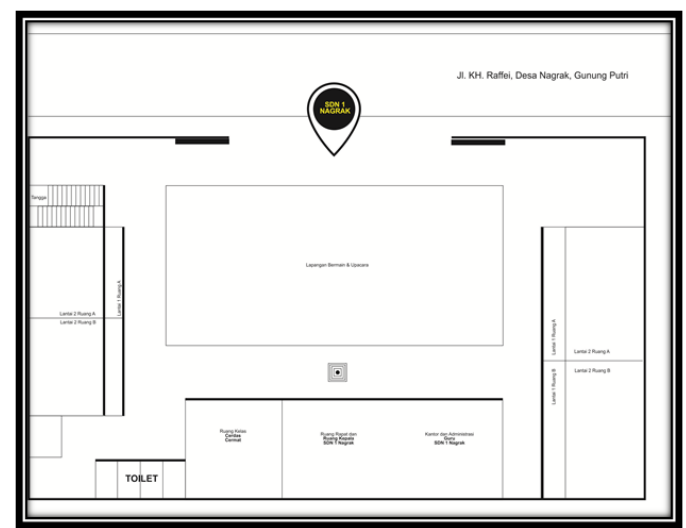

2nd Figure: House Building Plan School samples, Nagrak Village
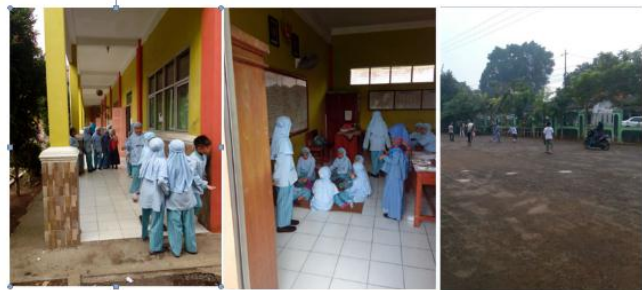

3rd Figure: Activity in School Samples, Nagrak Village

\section{Interview with Headmaster}

Interview of the research team on 31 May 2016 with Principal of School Samples, SD Negeri 1 Nagrak, Mr. Badrudin, S.Pd. Discusses the activities that occur in schools related to the student code of ethics.

\section{Thematic Discussion with Teachers of Primary School}

Discussion with teacher team of school samples in discussing about behavior and education dynamics that happened at SD Negeri 1 Nagrak. The discussion discussed with the teacher eventually becomes the input to the team to form a directive sentence that is appropriate to the student's condition at the school.
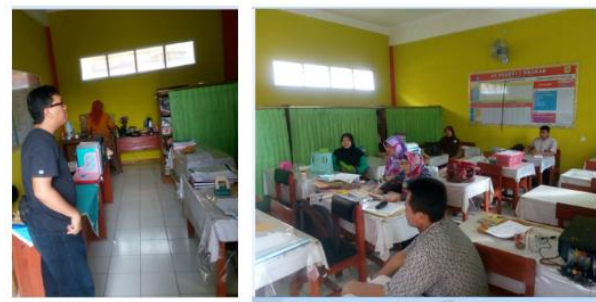

4th Figure: Discussion with Teacher Teams of School Samples, Nagrak Village

The results of the discussion with the teacher resulted in seven points of ethical code, the next being converted into a sentence/idea directive as the writing to be poured inside the poster. Sentences include:

1st Table: Sentence Directive on Poster Based on Student Code of Ethics

\begin{tabular}{ccc}
\hline No & Code of Ethics & Directive Sentence on Poster \\
\hline 1 & Menjalankan ibadah sesuai dengan agama yang & \\
dianutnya & Mulailah belajar dengan berdoa! \\
& (perform the worship in accordance with the & (Beligion it embraces)
\end{tabular}




\begin{tabular}{|c|c|c|}
\hline No & Code of Ethics & Directive Sentence on Poster \\
\hline 2 & $\begin{array}{l}\text { Menghormati pendidik dan tenaga kependidikan } \\
\text { (respect for educators and education personnel) }\end{array}$ & $\begin{array}{l}\text { Ingat nasihat baik bapak dan ibu guru! } \\
\text { (Remember good advice from teacher!) }\end{array}$ \\
\hline 3 & $\begin{array}{l}\text { Mengikuti proses pembelajaran dengan } \\
\text { menjunjung tinggi ketentuan pembelajaran dan } \\
\text { mematuhi semua peraturan yang berlaku. } \\
\text { (Following the learning process by upholding the } \\
\text { provisions of learning and complying with all } \\
\text { applicable regulations.) }\end{array}$ & $\begin{array}{c}\text { Kita bangga karena rajin belajar dan tertib } \\
\text { aturan } \\
\text { (We are proud because of diligent study and } \\
\text { orderly rules) }\end{array}$ \\
\hline 4 & $\begin{array}{l}\text { Memelihara kerukunan dan kedamaian untuk } \\
\text { mewujudkan harmoni sosial di antara teman. } \\
\text { (Maintaining harmony and peace to achieve } \\
\text { social harmony among friends.) }\end{array}$ & $\begin{array}{l}\text { Mari berlomba berbuat kebaikan kepada } \\
\text { sesama teman! } \\
\text { (Let's do good to fellow friends!) }\end{array}$ \\
\hline 5 & $\begin{array}{l}\text { Mencintai keluarga, masyarakat, dan menyayangi } \\
\text { sesama. } \\
\text { (Loving family, community, and loving others.) }\end{array}$ & $\begin{array}{c}\text { Ayah ibu bangga karena kita menyayangi } \\
\text { sesama } \\
\text { (Father and mother are proud because we } \\
\text { love each other) }\end{array}$ \\
\hline 6 & $\begin{array}{l}\text { Mencintai lingkungan, bangsa, dan negara. } \\
\text { (Loving the environment, the nation, and the } \\
\text { country) }\end{array}$ & $\begin{array}{l}\text { Kalau bersih, indonesia bangga } \\
\text { (If it is clean, Indonesia is proud) }\end{array}$ \\
\hline 7 & $\begin{array}{l}\text { Menjaga dan memelihara sarana dan prasarana, } \\
\text { kebersihan, ketertiban, keamanan, keindahan, } \\
\text { dan kenyamanan sekolah. } \\
\text { (Maintain facilities and infrastructure, } \\
\text { cleanliness, order, security, beauty, and comfort } \\
\text { of the school) }\end{array}$ & $\begin{array}{l}\text { Jaga \& rawat sarana sekolah } \\
\text { (Take care of school facilities) }\end{array}$ \\
\hline
\end{tabular}

\section{Illustration Design Process and Sentences Directive in Poster}

The illustration design process is tailored to the directive sentences that have been prepared and approved by the school. The illustrations are made are as follows,

2nd Table: Illustrations of Sentences Posed on Poster

\begin{tabular}{|c|c|c|}
\hline No & Directive Sentence on Poster & Illustrations \\
\hline 1 & $\begin{array}{l}\text { Mulailah belajar dengan berdoa! } \\
\text { (Begin your study by praying!) }\end{array}$ & A student is praying fervently \\
\hline 2 & $\begin{array}{l}\text { Ingat nasihat baik bapak dan ibu guru! } \\
\text { (Remember good advice from teacher!) }\end{array}$ & $\begin{array}{l}\text { Students walk with three balloons containing } \\
\text { messages from the teacher (studying diligently, } \\
\text { discipline time, reaching goals) }\end{array}$ \\
\hline 3 & $\begin{array}{c}\text { Kita bangga karena rajin belajar dan } \\
\text { tertib aturan } \\
\text { (We are proud because of diligent } \\
\text { study and orderly rules) }\end{array}$ & $\begin{array}{l}\text { One student with three expressions in different } \\
\text { learning activities (painting, reading, counting) } \\
\text { A student is reading a book of big size }\end{array}$ \\
\hline 4 & $\begin{array}{l}\text { Mari berlomba berbuat kebaikan } \\
\text { kepada sesama teman! } \\
\text { (Let's do good to fellow friends!) }\end{array}$ & $\begin{array}{l}\text { Two students were sharing food and drink to a } \\
\text { student. }\end{array}$ \\
\hline 5 & $\begin{array}{c}\text { Ayah ibu bangga karena kita } \\
\text { menyayangi sesama } \\
\text { (Father and mother are proud because } \\
\text { we love each other) }\end{array}$ & One woman is giving alms to the poor \\
\hline 6 & $\begin{array}{l}\text { Kalau bersih, indonesia bangga } \\
\text { (If it is clean, Indonesia is proud) }\end{array}$ & $\begin{array}{l}\text { A student pose a superhero by reading the } \\
\text { complete hygiene kits. }\end{array}$ \\
\hline 7 & $\begin{array}{l}\text { Jaga \& rawat sarana sekolah } \\
\text { (Take care of school facilities) }\end{array}$ & $\begin{array}{l}\text { Two students were cleaning one seat } \\
\text { (representation of school facilities) }\end{array}$ \\
\hline
\end{tabular}

After the directive sentence is formulated, the research team formulates the concept of illustration which gives the poster's identity position is the representation of the sample school attribute. Here is one illustration process that will be created. 


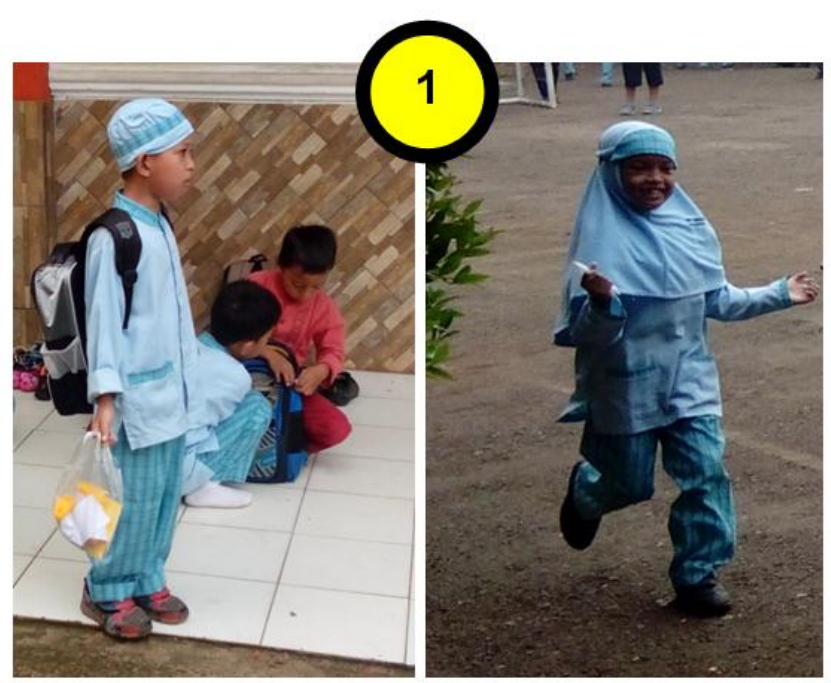

5th Figure: Illustration Process based on the representation of clothing and the behavior of school students (Source illustration)

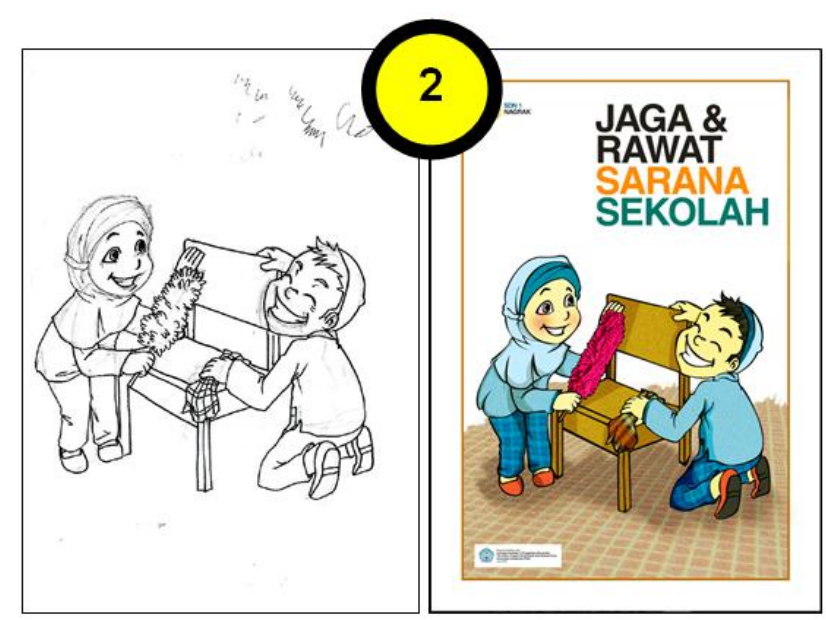

6th Figure: Illustration Process based on the representation of clothing and the behavior of school students (Illustrated results)

\section{Spanram Making Process (Frame) Poster Works}

A $120 \times 80 \mathrm{~cm}$ poster is placed on the school wall. Here's the details of the work in the process of making a poster,

1. The manufacture of spanram requires 19 teak teak wood which each has a length of $200 \mathrm{~cm}$ with a thickness of $3 \mathrm{~cm}$.

2. For one poster requires a spanram frame of $250 \mathrm{~cm}$ teak.

3. Works process requires tools including: saw, stepgun, stationery, meter, elbow, pliers, and hammer.

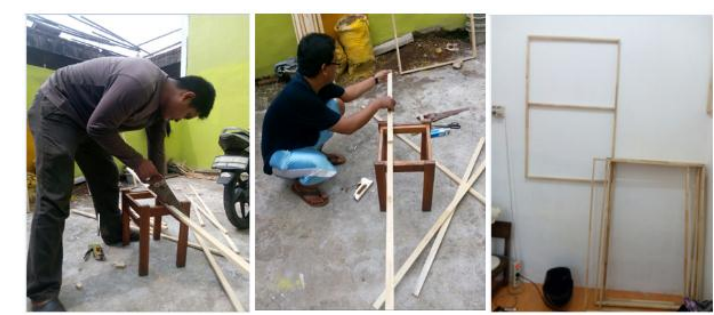

7th Figure: The process of making the spanram 


\section{Poster Results}

Illustrated poster that has been designed, to be next put together with a frame that has been created so that it has a more elegant and easy to apply posters. Here's an example of a finished poster.

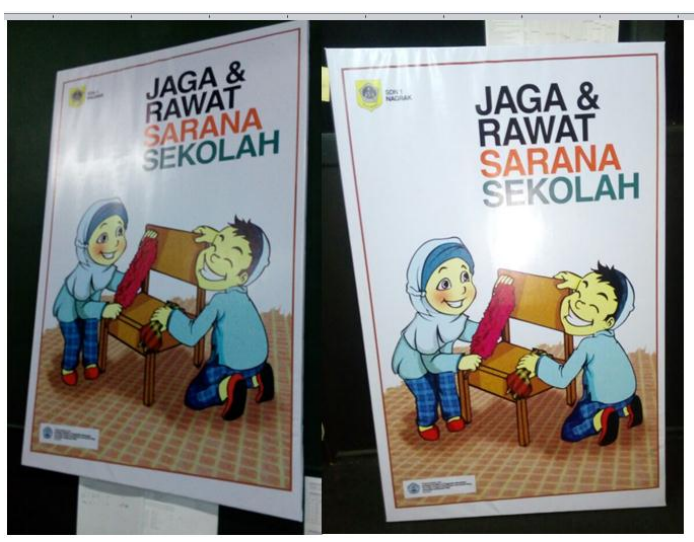

8th Figure: Result of 7th ethics code poster

\section{Handover of Posters to School Parties}

Posters completed by the team on student code of ethics, on 10 August 2016 submitted to the school, in this case is SD Negeri 1 Nagrak as an example school to serve as a visual educational tool which is then installed at several points in the school building. The process of installing posters in the school building was adapted to the request of the principal, $\mathrm{Mr}$. Badrudin, S.Pd. At a place that is considered strategic and easily visible to students.

By making design work based on school code of ethics, it is hoped that there will be stimulation and change of way of thinking from school people to always practice behavioral code of ethics both in school and community.

The application of poster-shaped design which contains denotative text with the code of ethics of students, is expected to further stimulate the students to consciously or unconsciously apply it in life. Thus, various cases that occur among students such as fights, torture, conflicts, and other delinquencies can be suppressed and minimized. Although it will take time and process, but at least the process can be done as early as possible so that the results can be seen immediately.

\section{CONCLUSION}

There are seven student codes of ethics that have been identified through the Regulation of the Minister of National Education of Indonesia Number 19 of 2007, among others, (1) to perform the worship in accordance with the religion it embraces; (2) respect for educators and education personnel; (3) follow the learning process by upholding the provisions of the lesson and complying with all applicable regulations; (4) maintaining harmony and peace to achieve social harmony among friends; (5) loving family, community, and loving others; (6) love the environment, nation and state; And (7) maintain facilities and infrastructure, hygiene, orderliness, safety, beauty, and comfort of the school.

From the code of ethics of students who have been identified, then, it converted into several directive sentences that are tailored to the student situation in the school to be applied into the spanram (poster): (1) Begin your study by praying; (2) Remember good advice from teacher; (3) We are proud because of diligent study and orderly rules; (4) Let's do good to 
fellow friends; (5) Father and mother are proud because we love each other; (6) If it is clean, Indonesia is proud; (7) Take care of school facilities.

\section{REFERENCES}

Anitah, S. (2008). Media Pembelajaran. Surakarta: LPP UNS dan UNS Pers.

Kriyantono, R. Pemberdayaan Konsumen Televisi Melalui Keterampilan Media-Literacy dan Penegakan Regulasi Penyiaran. Journal of Penelitian Komunikasi, Media Massa dan Teknologi Informasi, vol 10 no 21, 2007 ISSN 1978-5518

Sachari, A. (2002). Estetika: Makna, Simbol dan Daya. Bandung: Penerbit ITB

Sudjana, N. \& Rivai A. (2010). Media Pengajaran. Bandung: Sinar Baru Algensindo.

Walker, J. A. (2010). Desain, Sejarah, Budaya: Sebuah Pengantar Komprehensif. Yogyakarta: Jalasutra. 